\title{
Assessment of Tissue Damage from Ultrasonic, Pneumatic and Combination Lithotripsy
}

Yuqing Cui ${ }^{1}$, Carl Sarkissian ${ }^{2}$, Kevin Mohsenian ${ }^{3}$, and Manoj Monga ${ }^{2}$

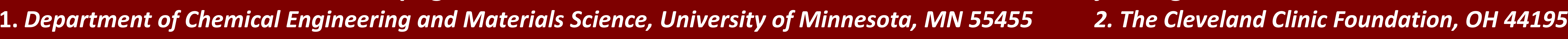

3. Department of Biomedical Engineering, University of Minnesota, MN 55455

\section{Introduction}

Percutaneous surgery is now a commonly used treatment for large or complex renal calculi (kidney stones). During a percutaneous nephrolithotomy (PCNL), a lithotripter is placed into the urinary tract through a small puncture wound (up to approximately $1 \mathrm{~cm}$ ) through the skin. A lithotripter can use two different energy sources to break up renal calculi, the pieces of which are suctioned out of the urinary tract. Ultrasonic and pneumatic energy are the two sources of energy commonly used in the urological field. The purpose of this experiment is to conduct a comparative evaluation of ultrasonic, pneumatic, and dual ultrasonic lithotripsy to predict the safety of probes on urinary tract tissue.

\section{Materials and Methods}

Lithotriptors tested were the Swiss Lithoclast Ultra (ultrasonic only - US, and ultrasonic-pneumatic combination US+P), and the Gyrus ACMI Cyberwand (dual ultrasonic). Fresh porcine ureters, bladders, and renal pelvis tissues were used for testing.
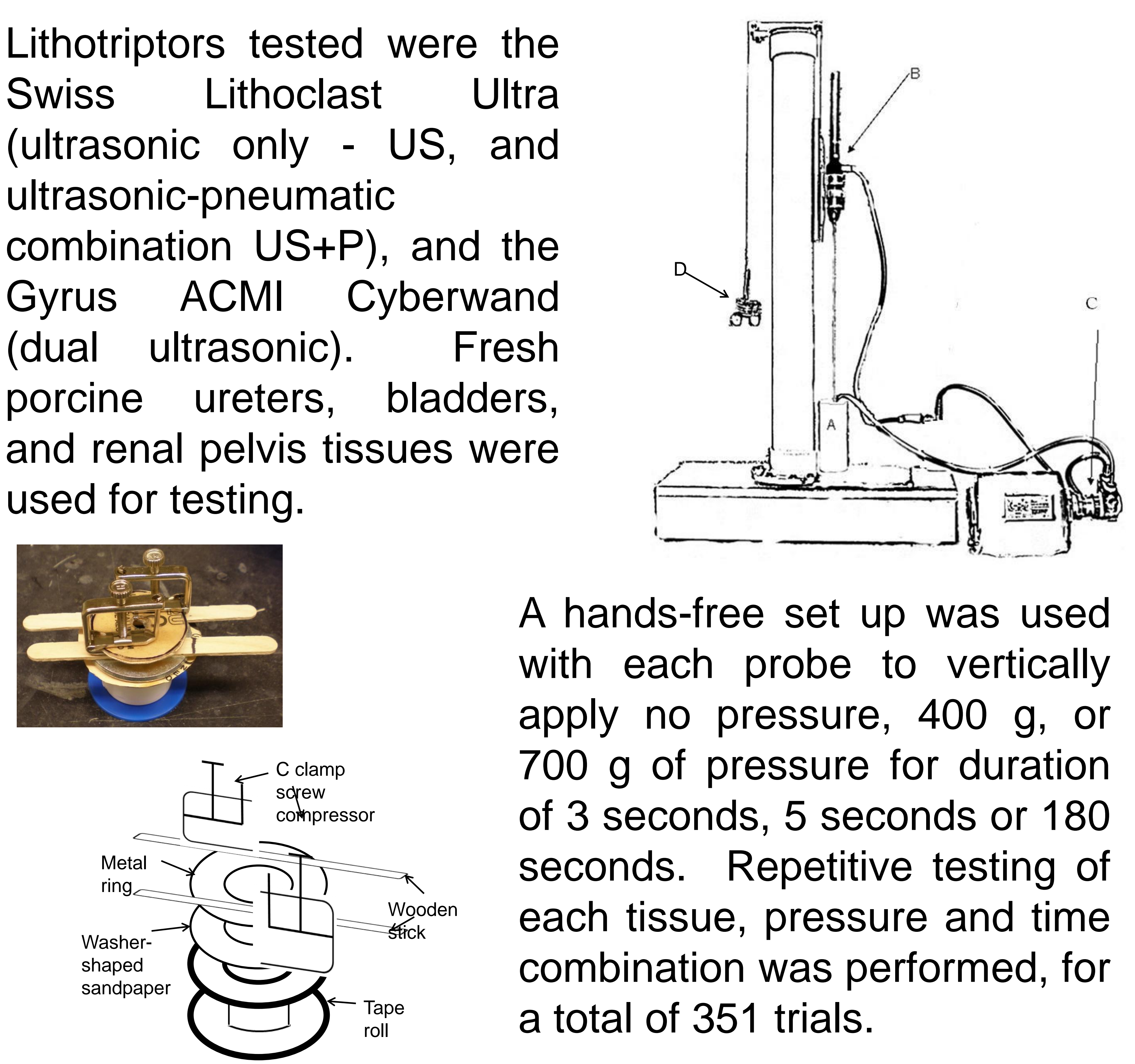

A hands-free set up was used with each probe to vertically apply no pressure, $400 \mathrm{~g}$, or $700 \mathrm{~g}$ of pressure for duration of 3 seconds, 5 seconds or 180 seconds. Repetitive testing of each tissue, pressure and time combination was performed, for a total of 351 trials.
The damage of tissue was graded on a score of 0 to 6 based on the time it took to perforate the tissue with 0 being the least damage and 6 being the most. The final score of each combination of independent variables was averaged among repeat trials. The detailed breakdown is shown in the following table.

\begin{tabular}{|c|c|c|c|c|c|c|c|}
\hline Score & 0 & 1 & 2 & 3 & 4 & 5 & 6 \\
\hline $\begin{array}{c}\text { Time of } \\
\text { perforation } \\
\text { (sec) }\end{array}$ & $\begin{array}{c}\text { No } \\
\text { perforation } \\
\text { in 180 sec }\end{array}$ & $151-180$ & $121-150$ & $91-120$ & $61-90$ & $31-60$ & $0-30$ \\
\hline
\end{tabular}

\section{Experimental results}

The damage score of all samples were zero at zero pressure, and renal pelvis tissues were only significantly damaged by Cyberwand dual ultrasonic operating mode at an equivalent pressure of $700 \mathrm{gm}$. Therefore, more analysis is done focusing on ureter and bladder tissue at 400 and 700 $\mathrm{gm}$ for the three devices. The comparison is presented in the following figures.

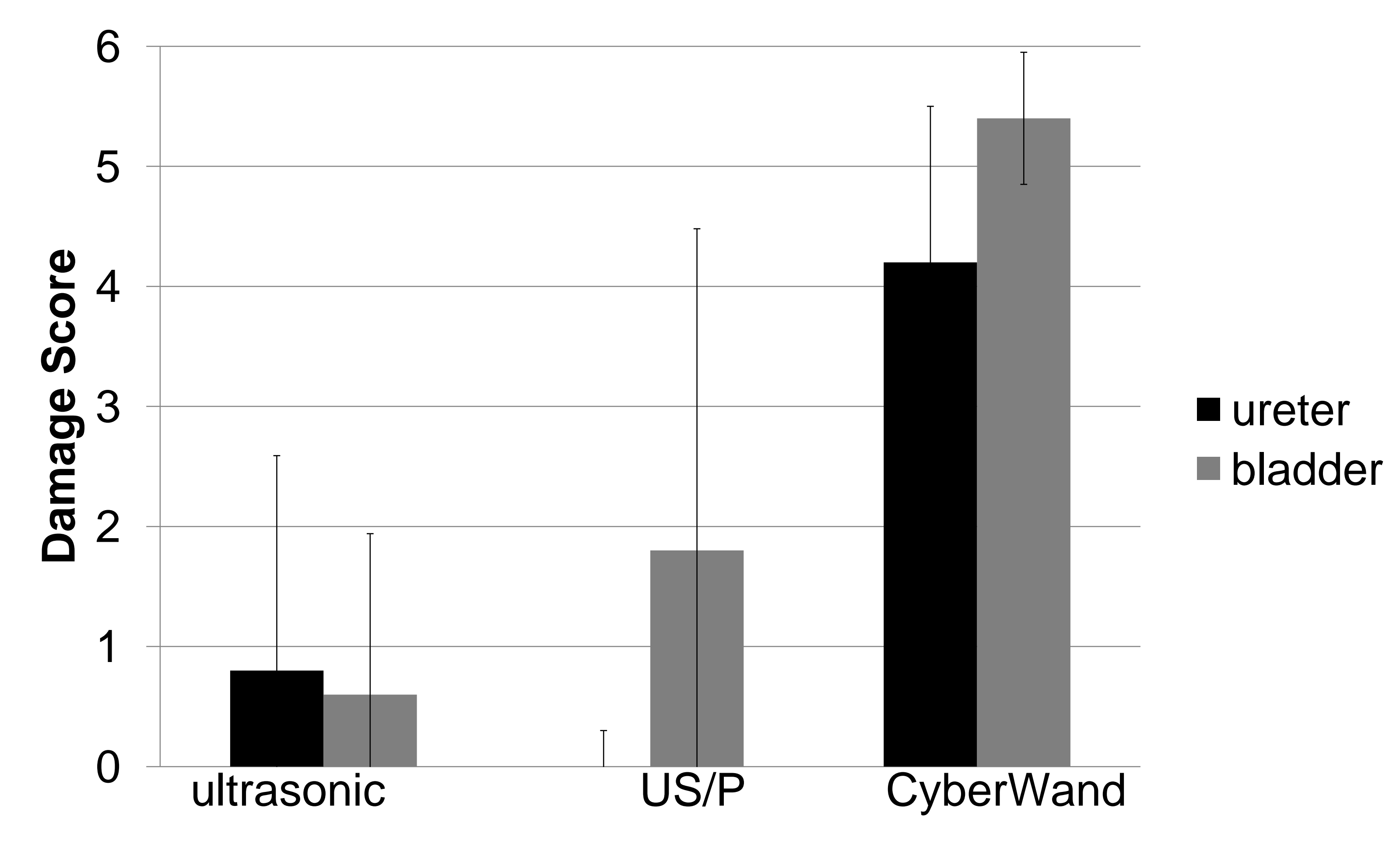

Comparison of three operating modes at $400 \mathrm{gm}$ of equivalent pressure

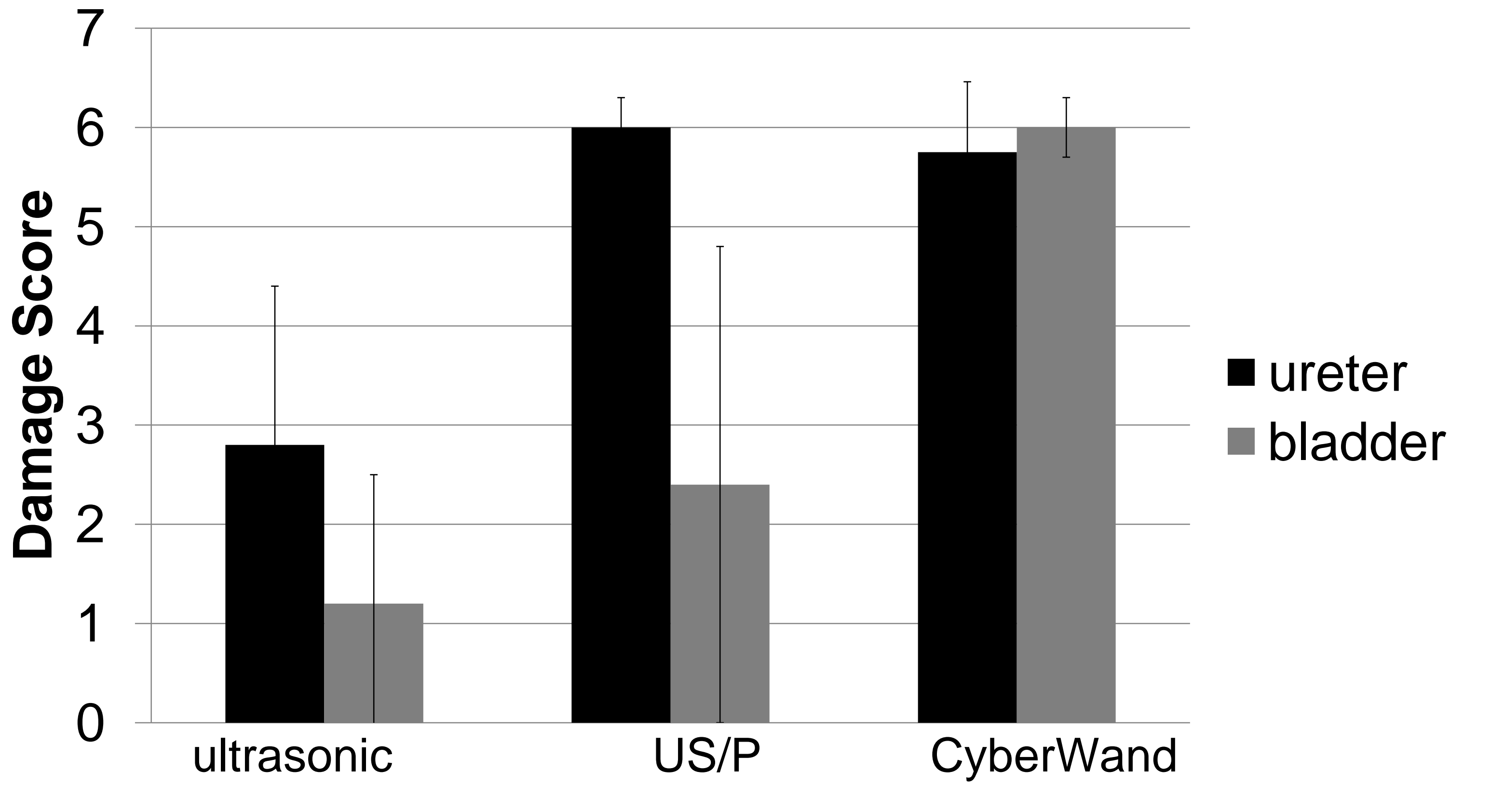

Comparison of three operating modes at $700 \mathrm{gm}$ of equivalent pressure

\begin{tabular}{|c|c|c|c|c|c|c|}
\hline & \multicolumn{2}{|c|}{ renal pelvis } & \multicolumn{2}{c|}{ ureter } & \multicolumn{2}{c|}{ bladder } \\
\hline & $3 \mathrm{sec}$ & $5 \mathrm{sec}$ & $3 \mathrm{sec}$ & $5 \mathrm{sec}$ & $3 \mathrm{sec}$ & $5 \mathrm{sec}$ \\
\hline US & 0 & 0 & 0 & 0 & 0 & 0 \\
\hline US+P & 0 & 0 & $40 \%$ & $80 \%$ & 0 & 0 \\
\hline CyberWand & 0 & 0 & $20 \%$ & $40 \%$ & $40 \%$ & $40 \%$ \\
\hline
\end{tabular}

\section{Conclusions}

All devices afforded a level of safety at tissue durations typical of inadvertent intraoperative contact (3-5 seconds) at low pressures, though the Lithoclast US-only was superior with regard to perforation for all tissue types. Overall, Cyberwand is more damaging to urinary trac tissues than Lithoclast US+P than Lithoclast US-only.

\section{References}

Preminger GM, Tiselius HG, Assimos DG, Alken P, Buck AC, Gallucci M et al: American Urological Association Education and Research, Inc., and European Association of Urology. 2007 Guideline for the management of ureteral calculi. Eur Urol 2007; 52: 1610 2. Goldman DM, Pedro RN, Kossett A, Durfee W, Monga M: Maximizing Stone Fragmentation 3iatsikos EN, Dinlenc CZ, Fogarty J Kapoor R, Bernardo NO and Smith AD: Efficiency and efficacy of different intracorporeal ultrasonic lithotripsy units on a synthetic stone model. $J$ Endourol; 15: 925 4. Auge BK, Lallas CD, Pietrow PK, Zhong P and Preminger GM: Invitro comparison of standard ultrasound and pneumatic lithotrites with a new combination intracorporeal lithotripsy device. Urology 2002; 60: 28 .

- Ultrasonic, pneumatic and combination intracorporeal lithotripsy for percutaneous nephrolithotomy. J Endourol 2009; (10): 1663-8
6. Kim SC, Matlaga BR, Tinmouth WW, Kuo RL, Evan AP, McAteer JA, Williams JC Jr, Lingeman JE: In vitro assessment of a novel dual probe ultrasonic intracorporeal lithotripter. J Urol 2007;

177(4): 1363-5
7. Louie MK, Lowe G, Knudsen BE: Comparison of the Lithoclast Ultra@ and Cyberwand in a 8. Leveillee RJ, Lobik L.: Intracoporeal lithotripsy: which modality is best? Curr Opin Urol. 2003; 13(3): 249-53 